\section{Report raises hopes for grand network of US ecology centres}

\section{Rex Dalton, San Diego}

The US National Academy of Sciences

(NAS) has endorsed the creation of an ambitious network of ecological research stations that the National Science Foundation has been advocating for the past six years.

The National Ecological Observatory Network (NEON) will provide a system for continental-scale experiments on ecological systems and will assist in predicting environmental change.

Congressional funding for NEON whose observatories could cost $\$ 20$ million each to build, plus $\$ 3$ million in annual operating costs - has repeatedly been stalled for political or budgetary reasons. Supporters hope that the NAS report, completed last week after four months of study, will encourage Congress to fund the \$12-million first phase during the 2004 federal fiscal year beginning on 1 October. A funding decision will be made within the next few weeks.

The 77-page NAS report, compiled by a panel of 14 scientists, recommends that NEON should concentrate on six major ecological observatories: biodiversity, biogeochemical cycles, climate change, infectious diseases, invasive species and habitat alternation.

The NSF had initially proposed 17 observatories, but the panel says that concentrating on six ecological issues would allow a better focus. "We think it will produce better science this way," says David Tilman, a plant ecologist at the University of Minnesota in MinneapolisSt Paul, who chaired the NAS panel.

A NEON observatory would include a core site linked by the Internet to satellite facilities and complementary institutions such as a university, government lab or museum. The core site would concentrate instrumentation for data collection, processing and analysis. Scientists in the complementary organizations could then study a target ecological issue in a variety of environments, from grasslands to forests and deserts to waterways.

John Aber, a biogeochemist at the University of New Hampshire in Durham and a NAS panel member, says that the committee has given the NSF flexibility to create NEONs through competition.

"The first NEON observatory should be national in scope," says Aber. But it will be up to the NSF to decide whether competitions should be launched in all six areas, or in only one, in the first round of funding, he adds.

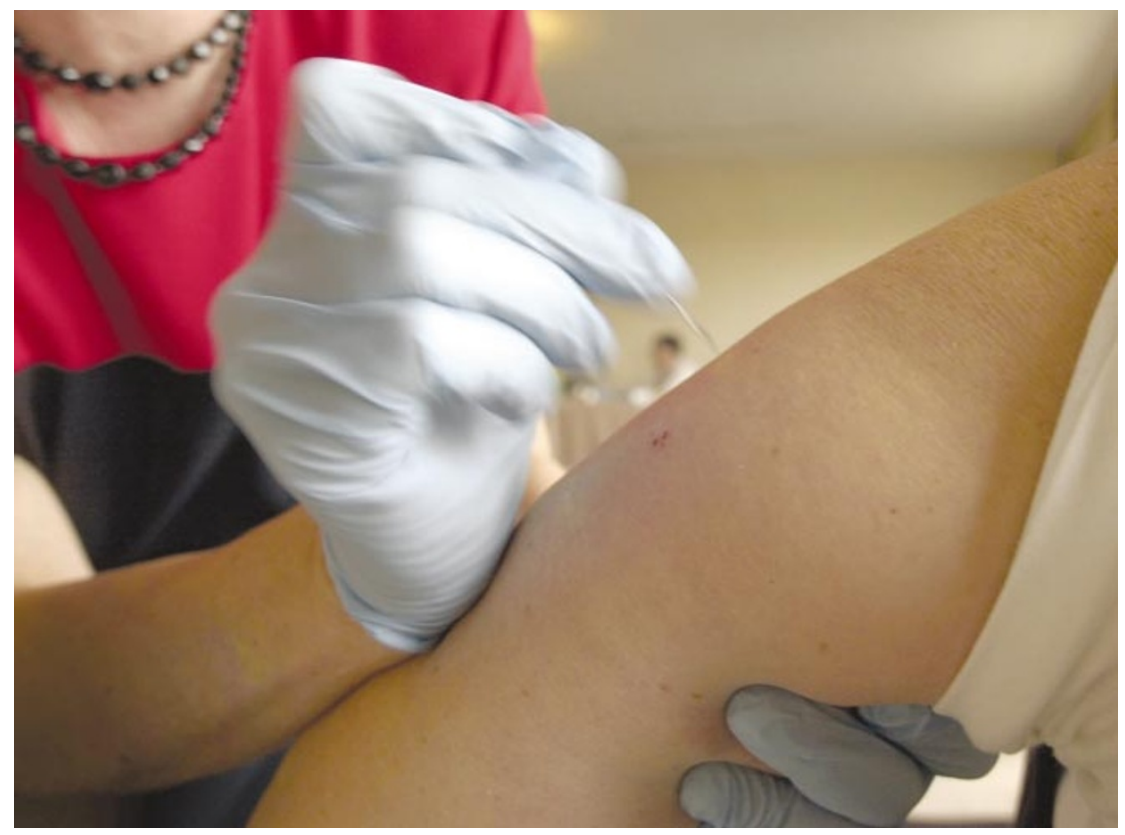

Lab jab: researchers have claimed in a press release that smallpox vaccination boosts HIV immunity.

\title{
Vaccine claim lifts company's stock but angers researchers
}

\section{Erika Check, Washington}

A press-released claim that the smallpox vaccine could increase immunity to HIV has boosted share prices of the vaccine's manufacturers - but has been met with hostile scepticism by the scientific community.

The claim, made by researchers at George Mason University in Fairfax, Virginia, on 11 September, has not been substantiated by published data. Other scientists are particularly annoyed at the unconventional method of the announcement, because of the claim's potential implications for past and future smallpox-vaccination programmes.

Raymond Weinstein, a researcher at George Mason's National Center for Biodefense, who led the research, says he noticed that the countries where smallpox had been eradicated first now have the highest rates of HIV infection. Together with Ken Alibek, a former Soviet bioweapons scientist who is now at George Mason, he directed a study by microbiologists at George Washington University Medical Center in Washington DC. Blood was tested from ten volunteers who had been vaccinated against smallpox, and ten who had not. The team claims that blood cells from vaccinated subjects became infected with four times less HIV than cells from unvaccinated subjects. Smallpox and HIV can both use the same cell-surface protein to infect cells, so it is plausible that there may be a link between immunity to the two diseases, claims Weinstein.

Weinstein says that the team then briefed officials at the National Institutes of Health and its parent agency, the Department of Health and Human Services. They decided to announce their findings in a press release, he says, because federal scientists warned them that they might try to race a study of their own into publication.

But Ed Tramont, director of the Division of AIDS at the National Institute of Allergy and Infectious Diseases in Bethesda, Maryland, says that he is not aware of any scientists working on duplicating the results. And he cautions against overinterpreting the press-released data. Many vaccinations cause temporary boosts in immunity soon after patients receive them, he says, and many adults who received the smallpox vaccine as children have subsequently contracted HIV.

Donald Henderson, a major architect of the smallpox-eradication plan and an adviser to the federal government on bioterrorism preparedness, says that there is in any case no consistent relationship between smallpox eradication and HIV emergence in Africa. "It doesn't make a lot of sense," he says.

But on the day that Weinstein and Alibek made their announcement, shares in smallpox-vaccine manufacturer Acambis jumped by $10 \%$ to a new high. And even though vaccine-maker VaxGen had announced earlier this year that its experimental HIV vaccine failed in clinical trials, its shares also rose by $10 \%$. 